\title{
IMPACT OF INTEGRATED WEED MANAGEMENT ON BULB YIELD OF ONION
}

\author{
M.R. Islam ${ }^{1}$, M. Moniruzzaman ${ }^{2}$, A.J.M. Obaidullah ${ }^{1}$ and A.H.F. Fahim ${ }^{3}$ \\ 1S.O., RSRC, BARI, Magura, ${ }^{2}$ S.S.O., RSRC, BARI, Magura, ${ }^{3}$ S.O., SRC, BARI, Bogura \\ Corresponding E-mail: rislamriaz@gmail.com
}

(Received: 12 May 2020, Accepted: 17 July 2020)

Keywords: Onion, BARI Piaz-1, weed, oxadiazon

\begin{abstract}
The experiment was conducted at Regional Spices Research Centre, Bangladesh Agricultural Research Institute, Magura, Bangladesh during 2016-2017 and 20172018 to optimize weed management practice for onion bulb production through Integrated Weed Management (IWM). The experiment was laid out in a Randomized Complete Block Design with three replications. Two different herbicides (Oxadiazon and Pendimethalin) with different doses in combination with hand weeding (HW) were used as treatments. The total number of treatments were $12 \mathrm{viz}$. $\mathrm{T}_{1}=$ Oxadiazon@1.0 l/ha, $\mathrm{T}_{2}=$ Oxadiazon@1.5 l/ha, $\mathrm{T}_{3}=$ Oxadiazon@2.0 l/ha, $\mathrm{T}_{4}=$ Oxadiazon@1.0 l/ha + one HW at 45 DAT (Days After Transplanting), $\mathrm{T}_{5}=$ Oxadiazon@1.5 l/ha + one HW at 45 DAT, $\mathrm{T}_{6}=$ Oxadiazon@2.0 l/ha + one HW at 45 DAT, $\quad \mathrm{T}_{7}=$ Pendimethalin@1.0 l/ha, $\mathrm{T}_{8}=$ Pendimethalin@1.5 l/ha, $\mathrm{T}_{9}=$ Pendimethalin@1.0 l/ha + HW at 45 DAT, T $10=$ Pendimethalin@1.5 l/ha+ HW at 45 DAT, $\mathrm{T}_{11}=$ Weed free and $\mathrm{T}_{12}=$ Weedy check (control). The onion var. BARI Piaz-1 was used as the test crop. The highest bulb yield ( 7.63 tha ${ }^{-1}$ in $2016 \& 9.56$ $t$ ha $^{-1}$ in 2017) and benefit cost ratio (2.14 in 2016 and 2.46 in 2017) were obtained from $\mathrm{T}_{6}=$ Oxadiazon@2.0 l/ha + one hand weeding at 45 DAT while the lowest bulb yield (4.22 $\mathrm{t} \mathrm{ha}^{-1}$ in 2016 and $6.28 \mathrm{t} \mathrm{ha}^{-1}$ in 2017) was obtained from $\mathrm{T}_{12}=$ Weedy check (control), while lowest benefit cost ratio (1.33 in 2016 and 1.74 in 2017) from treatment $T_{11}=$ Weed free. It was concluded that Oxadiazon@2.0 1/ha with one hand weeding at 45 days after transplanting performed better for controlling weed and maximizing bulb yield of onion.
\end{abstract}

\section{Introduction}

Onion (Allium cepa L.) belongs to the family Alliaceae, a group that includes bulb crops. It is a condiment crop consumed fresh and dry as a spice and one of the most important vegetable crops in the world (Ray and Yadav, 2005). Onion is a very important and major spice crop in Bangladesh. It ranks the first in production among the spices crops cultivated in the country. About 17, 37, 714 matric tones of onion produces from 4, 41, 105 acres of land during 201718 (BBS, 2018). Weeds are one of the main plant protection problems in onion fields. They compete with onions for light, nutrients, water, space and also are host plants of several harmful insects and pathogens (Dunan et al., 1996, Kizilkaya et al., 2001, Ghoshel, 2004, Qasem, 2006 , Smith et al., 2008). As in many crops, weeds cause yield reduction in onions owing to slow emergence, low initial growth rate, long vegetative period and low competitive ability of the crop (Boyham et al., 2016). Onion is poor competitor against weeds due to their slow, vertical growth that fails to shade out weeds (Kizilkaya et al., 2001). Uncontrolled weed growth caused 
49 to 86 percent reduction in bulb yield of onion compared with the best herbicidal treatment (James and Harlen, 2010). Lack of effective and economically viable weed management options for onion production has been reported as a critical constraint affecting farmers' motivation to grow the crop (Waiganjo, 2004). The conventional method of weed control i.e. hand weeding and hoeing are vary laborious, time consuming and expensive. Weedicides applied at the preemergence stage, significantly controlled the weed population (Nargis et al., 2006). Panse et al. (2014) reported that post-emergence herbicides kill weeds and keep the hardy weeds under control by arresting their growth through various kinds of deformities in foliage and growing points. On the other hand, Patel et al. (2012) was found that the application of pre-emergence herbicide followed by one hand weeding was effective for higher yield of onion. For controlling weed, integrated management through cultural, mechanical and herbicidal methods could be more efficient than single methods because onion is a narrow leafed crop and the herbicides which do not herm onion also may not herm the narrow leafed weed. Therefore, the present study was undertaken to optimize weed management practice for onion bulb production through Integrated Weed Management (IWM).

\section{Materials and Methods}

The experiment was conducted at Regional Spices Research Centre, Bangladesh Agricultural Research Institute, Magura during the year 2016-2017 and 2017-2018. The land was medium high land and clay loam in texture having $\mathrm{pH}$ of7.55. The unit plot size was $3.0 \mathrm{~m} \times 1.5 \mathrm{~m}$. The most popular onion variety BARI Piaz-1 was used with 42 days old seedlings. The crop was transplanted maintaining $15 \mathrm{~cm} \times 10 \mathrm{~cm}$ spacing. The experiment was laid out in Randomized Complete Block Design with three replications. Two different herbicides (Oxadiazon and Pendimethalin) with different doses in combination with hand weeding (HW) were used as the treatment variables. The total number of treatments were $12 \mathrm{viz} . \mathrm{T}_{1}=$ Oxadiazon@1.0 l/ha, $\mathrm{T}_{2}=$ Oxadiazon@1.5 l/ha, $\mathrm{T}_{3}=$ Oxadiazon@2.0 l/ha, $\mathrm{T}_{4}=$ Oxadiazon@1.0 l/ha + one HW at 45 DAT (Days After Transplanting), $\mathrm{T}_{5}=$ Oxadiazon@1.5 $\mathrm{l} / \mathrm{ha}+\mathrm{HW}$ at $45 \mathrm{DAT} \mathrm{T}_{6}=$ Oxadiazon@2.0 1/ha + HW at 45 DAT, $\quad \mathrm{T}_{7}=$ Pendimethalin@1.0 l/ha, $\mathrm{T}_{8}=$ Pendimethalin@1.5 l/ha, $\mathrm{T}_{9}=$ Pendimethalin@1.0 l/ha + HW at 45 DAT, $\mathrm{T}_{10}=$ Pendimethalin@1.5 l/ha + HW at $45 \mathrm{DAT}, \mathrm{T}_{11}=$ Weed free and $\mathrm{T}_{12}=$ Weedy check (control). The fertilizers were applied in the form of Urea, Triple Super Phosphate (TSP), muriate of potash (MoP), gypsum at the rate of $\mathrm{N}_{120} \mathrm{P}_{54} \mathrm{~K}_{75} \mathrm{~S}_{20} \mathrm{~kg} /$ ha respectively. Half of $\mathrm{N}, \mathrm{K}$ and full dose of $\mathrm{P}$ and $\mathrm{S}$ were applied at the time of final land preparation and remaining $\mathrm{N}, \mathrm{K}$ was top dressed into two equal splits at 25 and 50 days after transplanting (DAT). Four irrigations at 25 DAT, 45 DAT 70 DAT and 90 DAT were provided. The crop was harvested 110 days after transplanting. Data on plant height $(\mathrm{cm})$, number of leaves per plant, number of weed per $\mathrm{m}^{2}$, neck diameter $(\mathrm{cm})$, length of bulb $(\mathrm{cm})$, diameter of bulb $(\mathrm{cm})$, individual bulb weight $(\mathrm{g})$ and yield (tha-1) were collected. The Benefit Cost Ratio $(\mathrm{BCR})$ was calculated on the basis of prevailing local market price of onion bulbs and cost of inputs. Data on weed density (plantm ${ }^{-2}$ ), dry matter weight of weeds $\left(\mathrm{gm}^{-2}\right)$ were recorded from the standing crop by using quadrat of $1 \mathrm{~m}$ $\mathrm{x} 1 \mathrm{~m}$. Weed control efficiency (WCE) was calculated by using the following formula used by (Das, 2008).

$$
W C E(\%)=\frac{D M C-D M T}{D M C} \times 100
$$

Where, DMC was dry matter weight of weeds in control plot and DMT was dry matter of weeds in treated plots. The recorded data on yield and other parameters were statistically analyzed by using Statitix10 software. The difference between the treatments means were judged by Duncan's Multiple Range Test (DMRT) (Gomez and Gomez, 1984). 


\section{Results and Discussion}

\section{Effect on weed}

Different weed species were found in experimental plots. Among them, the prominent weed species were Cyperus rotundas, Chenopodium album, Cynodon dactylon, Amaranthus viridis, Amaranthus spinosus, Physalis heterophylla, Echinochloa crusgalli etc. Similar types of weed species were also reported in onion field (Karim et al., 2014, Naresh et al., 2002, Panse et al., 2014 and Syed and Malik, 2001). It was found that the weed density, dry weight of weed and weed control efficiency were varied significantly among the different treatment combinations (Table 1). The highest weed density (506.67 no. $\mathrm{m}^{-2}$ in $2016-17$ and 596.67 no. $\mathrm{m}^{-2}$ in $2017-$ 18 ), dry weight of weed (280.44 $\mathrm{g} \mathrm{m}^{-2}$ in 2016-17 and $307.29 \mathrm{~g} \mathrm{~m}^{-2}$ in 2017-18) and minimum weed control efficiency $(0 \%)$ was found in weedy check (control) plot. Because under this treatment no weeding was done and the plot was allowed to grow weed naturally. In this situation the weed covered the whole plot prior to the onion seedlings establishment and started to take soil nutrients and natural resources such as soil moisture, sunlight etc. The lowest weed density $\left(0\right.$ no. $\left.\mathrm{m}^{-2}\right)$, dry weight of weed $\left(0 \mathrm{~g} \mathrm{~m}^{-2}\right)$ and maximum weed control efficiency (100\%) was found in weed free plot. Because under this treatment weeding was done immediately the weeds appear on the plot as a result there was no competition between crop and weed for soil nutrient and natural resources. Among the herbicidal treatments lowest weed density (26.67 no. $\mathrm{m}^{-2}$ in 2016-17 and 26 no. $\mathrm{m}^{-2}$ in 2017-18), lowest dry weight of weed (35.67 $\mathrm{g} \mathrm{m}^{-2}$ in 201617 and $36.46 \mathrm{~g} \mathrm{~m}^{-2}$ in 2017-18) and maximum weed control efficiency (87.27\% in 2016-17 and $88.11 \%$ in 2017-18) was found from the application of Oxadiazon@2.0 1/ha with one hand weeding at 45 days after transplanting. That means Oxadiazon performed better than Pendimethalin in onion field for controlling weed. Similar results were also reported by Uygur et al. (2010).

Table 1.Effect of different weed management treatment on weed

\begin{tabular}{|c|c|c|c|c|c|c|}
\hline \multirow[t]{2}{*}{ Treatments } & \multicolumn{2}{|c|}{$\begin{array}{l}\text { Weed density } \\
\text { (plant } \mathrm{m}^{-2} \text { ) }\end{array}$} & \multicolumn{2}{|c|}{$\begin{array}{c}\text { Dry weight of } \\
\text { weed }\left(\mathrm{g} \mathrm{m}^{-2}\right)\end{array}$} & \multicolumn{2}{|c|}{$\begin{array}{l}\text { Weed control } \\
\text { efficiency (\%) }\end{array}$} \\
\hline & $2016-17$ & $2017-18$ & 2016-17 & $2017-18$ & $2016-17$ & $2017-18$ \\
\hline $\mathrm{T}_{1^{-}}$Oxadiazon@1.01/ha & $66.00 \mathrm{bc}$ & $54.00 \mathrm{bcd}$ & $85.45 b$ & $76.66 \mathrm{bcd}$ & $69.53 f$ & $75.12 \mathrm{f}$ \\
\hline $\mathrm{T}_{2^{-}}$Oxadiazon@1.5 l/ha & $59.00 \mathrm{bcd}$ & $45.00 \mathrm{~cd}$ & 77.07c & $77.76 b c$ & $72.50 e$ & $74.68 f$ \\
\hline $\mathrm{T}_{3}$ - Oxadiazon@2.0l/ha & 54.00 cde & $45.00 \mathrm{~cd}$ & $70.49 \mathrm{~d}$ & $68.53 d$ & $74.85 \mathrm{~d}$ & $77.68 \mathrm{~d}$ \\
\hline $\mathrm{T}_{4}$ - Oxadiazon@1.0 l/ha + HW & $47.00 \mathrm{de}$ & $51.00 \mathrm{~cd}$ & $63.44 e f$ & $74.63 \mathrm{bcd}$ & $77.37 \mathrm{c}$ & 75.71ef \\
\hline $\mathrm{T}_{5}$ - Oxadiazon@1.5 l/ha + HW at 45 DAT & $43.00 \mathrm{e}$ & 37.00 cde & $70.37 \mathrm{~d}$ & $55.15 e$ & $74.90 \mathrm{~d}$ & $82.04 \mathrm{c}$ \\
\hline $\mathrm{T}_{6}$ - Oxadiazon@2.0 l/ha + HW at 45 DAT & $26.67 \mathrm{f}$ & $26.00 \mathrm{de}$ & $35.67 \mathrm{~g}$ & $36.46 f$ & $87.27 b$ & $88.11 b$ \\
\hline $\mathrm{T}_{7}$ - Pendimethalin@1.01/ha & $68.00 \mathrm{~b}$ & $92.00 \mathrm{~b}$ & $77.44 \mathrm{c}$ & $54.84 e$ & $72.34 e$ & $82.13 c$ \\
\hline $\mathrm{T}_{8}-$ Pendi & $64.00 \mathrm{bc}$ & $64.00 \mathrm{bcd}$ & $84.51 b$ & $80.06 b$ & $69.88 \mathrm{f}$ & $73.92 f$ \\
\hline $\mathrm{T}_{9}$ - Pendin & $50.67 \mathrm{de}$ & $74.00 \mathrm{bc}$ & $68.54 \mathrm{de}$ & $74.45 \mathrm{bcd}$ & $75.56 \mathrm{~d}$ & 75.76ef \\
\hline $\begin{array}{l}\mathrm{T}_{10} \text { - Pendimethalin@ } 1.5 \mathrm{l} / \mathrm{ha}+ \\
45 \text { DAT }\end{array}$ & $56.00 \mathrm{bcd}$ & $52.00 \mathrm{~cd}$ & $60.21 f$ & $70.63 \mathrm{~cd}$ & $78.51 \mathrm{c}$ & 76.99de \\
\hline$T_{11}-$ Weed free & $0 \mathrm{~g}$ & $0 e$ & 0 & 0 & $100 \mathrm{a}$ & $100 \mathrm{a}$ \\
\hline $\mathrm{T}_{12}$-Weedy check & $506.67 a$ & $596.67 a$ & $280.44 a$ & $307.29 a$ & $0.00 \mathrm{~g}$ & $0.00 \mathrm{~g}$ \\
\hline Level of $\mathrm{si}$ & $* * *$ & $*$ & $* *$ & $* *$ & ** & *** \\
\hline CV $(\%)$ & 8.23 & 24.81 & 4.47 & 6.47 & 1.29 & 1.49 \\
\hline
\end{tabular}

In a column, means followed by the same letter did not differ significantly by DMRT.

$\mathrm{HW}=$ Hand Weeding, DAT $=$ Days after transplanting,

$*=5 \%$ level of significance and ${ }^{* *}=1 \%$ level of significance. 


\section{Effect on growth parameters}

Growth characters of onion as influenced by different treatments revealed significant variations (Table 2). The longest plant $(52.27 \mathrm{~cm}$ in 2016 and $52.36 \mathrm{~cm}$ in 2017), higher number of leaves per plant (6.87 in 2016 and 7.47 in 2017) and higher neck diameter $(0.94 \mathrm{~cm}$ in 2016 and $1.27 \mathrm{~cm}$ in 2017 ) were recorded from the application of Oxadiazon@ 2.0 1/ha with one hand weeding at 45 days after transplanting. The shortest plant $(45.00 \mathrm{~cm}$ in 2016 and $46.63 \mathrm{~cm}$ in 2017), lower number of leaves per plant (5.07 in 2016 and 6.3 in 2017) and lowest neck diameter $(0.68 \mathrm{~cm}$ in 2016 and $0.97 \mathrm{~cm}$ in 2017) was recorded from weedy check (control) treatment. Because due to lacking of optimum environment under weedy condition all the growth parameters reduced and the crop has to survive competing with weeds. Similar results were reported by Uygur et al. (2010).

Table 2. Effect of different weed management treatments on growth parameters of onion

\begin{tabular}{|c|c|c|c|c|c|c|}
\hline \multirow[t]{2}{*}{ Treatments } & \multicolumn{2}{|c|}{$\begin{array}{l}\text { Plant height } \\
(\mathrm{cm})\end{array}$} & \multicolumn{2}{|c|}{$\begin{array}{l}\text { No. of leaves } \\
\text { plant }^{-1}\end{array}$} & \multicolumn{2}{|c|}{ Neck diameter $(\mathrm{cm})$} \\
\hline & 2016-17 & 2017-18 & 2016-17 & 2017-18 & 2016-17 & 2017-18 \\
\hline $\mathrm{T}_{1^{-}}$Oxadiazon@1.01/ha & $49.40 \mathrm{abc}$ & $48.58 e$ & $6.47 \mathrm{a}$ & $6.50 f$ & $0.89 \mathrm{a}$ & $1.00 \mathrm{de}$ \\
\hline $\mathrm{T}_{2^{-}}$Oxadiazon@1.5 l/ha & $50.20 \mathrm{abc}$ & $49.63 d$ & $6.27 \mathrm{a}$ & 6.63de & $0.89 a$ & $1.09 b c$ \\
\hline $\mathrm{T}_{3}$-Oxadiazon@2.01/ha & $50.07 \mathrm{abc}$ & $50.80 c$ & $5.60 \mathrm{ab}$ & $6.73 \mathrm{~d}$ & $0.79 \mathrm{ab}$ & $1.13 b$ \\
\hline $\begin{array}{l}\mathrm{T}_{4}-\text { Oxadiazon@ } 1.0 \mathrm{l} / \mathrm{ha}+ \\
\mathrm{HW} \text { at } 45 \mathrm{DAT}\end{array}$ & $51.40 \mathrm{a}$ & $50.62 c$ & $6.40 \mathrm{a}$ & $7.17 b$ & $0.90 \mathrm{a}$ & $1.23 \mathrm{a}$ \\
\hline $\begin{array}{l}\mathrm{T}_{5} \text { - Oxadiazon@1.5 l/ha }+ \\
\mathrm{HW} \text { at } 45 \mathrm{DAT}\end{array}$ & $49.60 \mathrm{abc}$ & $51.57 b$ & $6.60 \mathrm{a}$ & $7.27 b$ & $0.78 \mathrm{ab}$ & $1.27 \mathrm{a}$ \\
\hline $\begin{array}{l}\mathrm{T}_{6}-\text { Oxadiazon@2.0 1/ha + } \\
\mathrm{HW} \text { at } 45 \text { DAT }\end{array}$ & $52.27 \mathrm{c}$ & $52.36 \mathrm{a}$ & $6.87 \mathrm{a}$ & $7.47 a$ & $0.94 \mathrm{a}$ & $1.27 \mathrm{a}$ \\
\hline $\mathrm{T}_{7}$ - Pendimethalin@1.01/ha & $48.13 \mathrm{c}$ & $48.60 e$ & $5.80 \mathrm{ab}$ & $6.60 e f$ & $0.74 \mathrm{ab}$ & $1.02 \mathrm{cde}$ \\
\hline $\mathrm{T}_{8}$ - Pendimethalin@1.5 l/ha & 48.47 bc & $48.69 e$ & $6.40 \mathrm{a}$ & 6.67de & $0.81 \mathrm{ab}$ & 1.07cde \\
\hline $\begin{array}{l}\mathrm{T}_{9} \text { - Pendimethalin@1.0 l/ha + } \\
\mathrm{HW} \text { at } 45 \text { DAT }\end{array}$ & $51.20 \mathrm{ab}$ & $50.57 c$ & $6.40 \mathrm{a}$ & $7.03 c$ & $0.79 \mathrm{ab}$ & $1.09 b c$ \\
\hline $\begin{array}{l}\mathrm{T}_{10} \text { - Pendimethalin@ } 1.5 \mathrm{l} / \mathrm{ha} \\
+\mathrm{HW} \text { at- } 45 \text { DAT }\end{array}$ & $50.80 \mathrm{abc}$ & $51.26 \mathrm{~b}$ & $6.07 \mathrm{ab}$ & $7.20 b$ & $0.86 \mathrm{ab}$ & $1.13 b$ \\
\hline$T_{11}$ - Weed free & $48.20 \mathrm{c}$ & $49.47 d$ & $6.47 \mathrm{a}$ & 6.70 de & $0.82 \mathrm{ab}$ & $1.11 b$ \\
\hline $\mathrm{T}_{12}$-Weedy check (control) & $45.00 \mathrm{~d}$ & $46.63 f$ & $5.07 \mathrm{~b}$ & $6.30 \mathrm{~g}$ & $0.68 b$ & $0.97 e$ \\
\hline Level of significance & $* *$ & $* *$ & * & $* *$ & $* *$ & $* *$ \\
\hline $\mathrm{CV}(\%)$ & 3.52 & 2.65 & 10.12 & 8.64 & 9.26 & 13.46 \\
\hline
\end{tabular}

In a column, means followed by the same letter did not differ significantly by DMRT.

$\mathrm{HW}=$ Hand Weeding, DAT $=$ Days after transplanting,

$*=5 \%$ level of significance and ${ }^{* *}=1 \%$ level of significance.

\section{Effect on yield parameters}

The yield and yield contributing characters were varied significantly among the different treatment combinations (Table 3). The biggest bulb diameter $(3.54 \mathrm{~cm}$ in 2016 and $4.7 \mathrm{~cm}$ in 2017), longest bulb (3.51 cm in 2016 and $4.67 \mathrm{~cm}$ in 2017), heaviest individual bulb (13.20 g in 2016 and $29.72 \mathrm{~g}$ in 2017) and highest bulb yield (7.63 tha $\mathrm{a}^{-1}$ in 2016 and $9.56 \mathrm{t} \mathrm{ha}^{-1}$ in 2017) was recorded from the application of Oxadiazon@2.0 l/ha with one hand weeding at 45 days after transplanting. This is due to the effectiveness of Oxadiazon for controlling weed as well as proper timing of hand weeding. So, that the crop gets minimum crop weed competition and 
optimum growing environment. Similar results were recorded from Patel et al. (2012) and Uygur et al. (2010). The smallest bulb diameter $(2.44 \mathrm{~cm}$ in 2016 and $2.88 \mathrm{~cm}$ in 2017), shortest bulb (3.09 $\mathrm{cm}$ in 2016 and $2.96 \mathrm{~cm}$ in 2017), lightest individual bulb (8.34g in 2016 and $19.01 \mathrm{~g}$ in 2017) and lowest bulb yield (4.22 $\mathrm{t} \mathrm{ha}^{-1}$ in 2016 and $6.28 \mathrm{t} \mathrm{ha}^{-1}$ in 2017) were recorded from weedy check (control) treatment. Because, under weedy condition the growth parameters of onion such as height and number of leaves were reduced ultimately this lowers the accumulation of photosynthates on the bulb. Similar results on variation of onion yield due to different time of planting were also reported by Devulkar et al. (2015) and Misra et al. (2014). During the year 2017-2018, the bulb yield of onion was higher than the year 2016-2017, this was because of timely showing and transplanting of onion.

Table 3. Effect of different weed management treatments on bulb yield and yield contributing characters of onion

\begin{tabular}{|c|c|c|c|c|c|c|c|c|}
\hline \multirow[t]{2}{*}{ Treatments } & \multicolumn{2}{|c|}{$\begin{array}{l}\text { Bulb diameter } \\
(\mathrm{cm})\end{array}$} & \multicolumn{2}{|c|}{$\begin{array}{l}\text { Bulb length } \\
\text { (cm) }\end{array}$} & \multicolumn{2}{|c|}{$\begin{array}{l}\text { Single bulb weight } \\
\text { (g) }\end{array}$} & \multicolumn{2}{|c|}{$\begin{array}{l}\text { Bulb yield } \\
\text { (t ha-1) }\end{array}$} \\
\hline & $\begin{array}{c}2016- \\
17\end{array}$ & $\begin{array}{c}2017- \\
18\end{array}$ & $\begin{array}{c}2016- \\
17\end{array}$ & $\begin{array}{c}2017- \\
18\end{array}$ & $2016-17$ & $\begin{array}{c}2017- \\
18\end{array}$ & $\begin{array}{c}2016- \\
17\end{array}$ & $\begin{array}{c}2017- \\
18\end{array}$ \\
\hline $\mathrm{T}_{1}$ - Oxadiazon@1.01/ha & $3.10 \mathrm{ab}$ & $3.80 e f$ & $3.38 \mathrm{ab}$ & $3.93 f$ & $10.67 \mathrm{ab}$ & $28.66 \mathrm{k}$ & $6.85 \mathrm{abc}$ & 7.72ef \\
\hline $\mathrm{T}_{2}$ - Oxadiazon@1.5 l/ha & $3.11 \mathrm{ab}$ & $3.94 d$ & $3.40 \mathrm{ab}$ & $4.01 e$ & $11.23 \mathrm{abc}$ & $30.43 \mathrm{i}$ & $6.96 \mathrm{abc}$ & 8.06de \\
\hline T3- Oxadiazon@2.0 l/ha & $3.17 \mathrm{ab}$ & $4.14 \mathrm{c}$ & $3.52 \mathrm{ab}$ & $4.18 \mathrm{~d}$ & $11.58 \mathrm{ab}$ & $34.73 e$ & 7.00abc & $8.09 \mathrm{~d}$ \\
\hline T4 - Oxadiazon@1.0 l/ha + HW at 45 DAT & $3.27 \mathrm{ab}$ & $4.35 b$ & $3.61 \mathrm{a}$ & $4.33 c$ & $11.56 \mathrm{ab}$ & $38.45 c$ & 6.98abc & $8.56 b c$ \\
\hline $\mathrm{T}_{5}$ - Oxadiazon@1.5 l/ha + HW at 45 DAT & $3.08 \mathrm{ab}$ & $4.37 b$ & $3.58 \mathrm{a}$ & $4.55 b$ & $11.89 \mathrm{abc}$ & $42.86 b$ & 7.04abc & $8.89 b$ \\
\hline $\mathrm{T}_{6}$ - Oxadiazon@2.0 1/ha + HW at 45 DAT & $3.54 \mathrm{ab}$ & $4.75 a$ & $3.65 \mathrm{ab}$ & $4.67 a$ & $13.20 \mathrm{abc}$ & $44.58 \mathrm{a}$ & $7.63 \mathrm{a}$ & $9.56 a$ \\
\hline $\mathrm{T}_{7}$ - Pendimethalin@1.01/ha & $3.10 \mathrm{ab}$ & $3.75 f$ & $3.41 \mathrm{ab}$ & $3.84 \mathrm{~g}$ & 10. & $2 j$ & $6.29 \mathrm{bc}$ & $7.55 f$ \\
\hline $\mathrm{T}_{8}$ - Pendimethalin@1.5 l/ha & $3.41 \mathrm{a}$ & $3.87 \mathrm{de}$ & $3.42 \mathrm{ab}$ & 3.97ef & $9.49 a b c$ & $31.61 \mathrm{~h}$ & $6.51 b c$ & $7.67 f$ \\
\hline $\begin{array}{l}\mathrm{T}_{9} \text { - Pendimethalin@ } 1.0 \mathrm{l} / \mathrm{ha}+\mathrm{HW} \text { at } \\
45 \text { DAT }\end{array}$ & $3.12 \mathrm{ab}$ & $4.18 \mathrm{c}$ & $3.74 \mathrm{a}$ & $4.15 \mathrm{~d}$ & $13.27 \mathrm{a}$ & $33.06 \mathrm{~g}$ & $7.29 \mathrm{ab}$ & $8.22 \mathrm{~cd}$ \\
\hline $\begin{array}{l}\mathrm{T}_{10} \text { - Pendimethalin@1.5 l/ha + HW at- } \\
45 \text { DAT }\end{array}$ & $3.19 \mathrm{ab}$ & $4.35 b$ & $3.51 \mathrm{ab}$ & $4.13 \mathrm{~d}$ & $12.24 \mathrm{ab}$ & $37.66 \mathrm{~d}$ & 6.92abc & $8.57 b c$ \\
\hline $\mathrm{T}_{11}$ - Weed free & $2.85 \mathrm{bc}$ & $3.82 e f$ & $3.54 \mathrm{ab}$ & $3.76 \mathrm{~h}$ & $10.60 \mathrm{c}$ & $33.63 f$ & $6.07 c$ & $7.44 \mathrm{f}$ \\
\hline $\mathrm{T}_{12}$-Weedy check (control) & $2.44 \mathrm{c}$ & $2.87 \mathrm{~g}$ & $3.09 \mathrm{~b}$ & $2.95 \mathrm{i}$ & $8.34 \mathrm{~d}$ & 19.011 & $4.22 \mathrm{~d}$ & $6.28 \mathrm{~g}$ \\
\hline Level of significance & $* *$ & $* *$ & $*$ & $* *$ & ** & $* *$ & $* *$ & $* *$ \\
\hline CV (\%) & 9.25 & 7.34 & 8.05 & 5.64 & 12.42 & 9.34 & 9.39 & 7.58 \\
\hline
\end{tabular}

In a column, means followed by the same letter did not differ significantly by DMRT Test.

$\mathrm{HW}=$ Hand Weeding, DAT = Days after transplanting,

$*=5 \%$ level of significance and $* *=1 \%$ level of significance.

\section{Cost benefit analysis}

The economic performance of onion as influenced by different weed management practices are presented in the Table 4. The highest gross return as well as Benefit Cost Ratio (2.14 in 2016 and 2.46 in 2016) was found from the treatment $\mathrm{T}_{6}$ (Oxadiazon@2.0 l/ha + Hand at 45 DAT) and the lowest Benefit Cost Ratio(1.33 in 2016 and 1.74 in 2017) from treatment $T_{11}$ (weed free). This is because hand weeding is very laborious than spraying of herbicides also expensive and time consuming. Similar results also reported by Panse et al. (2014). 
Table 4. Economic performance of onion as influenced by different treatments

\begin{tabular}{lcccccc}
\hline Treatments & $\begin{array}{c}\text { Total cultivation } \\
\text { cost(Tk. ha }\end{array}$ & \multicolumn{2}{c}{$\begin{array}{c}\text { Gross return } \\
\text { (Tk. ha }\end{array}$} & & & BCR \\
& $2016-17$ & $2017-18$ & $2016-17$ & $2017-18$ & $2016-17$ & $2017-18$ \\
\hline $\mathrm{T}_{1}$ - Oxadiazon@1.0 l/ha & 115000 & 115000 & 239750 & 270200 & 2.08 & 2.35 \\
$\mathrm{~T}_{2}$ - Oxadiazon@1.5 l/ha & 118000 & 118000 & 243600 & 282100 & 2.06 & 2.39 \\
$\mathrm{~T}_{3}$ - Oxadiazon@2.0 l/ha & 121000 & 121000 & 245000 & 283150 & 2.02 & 2.34 \\
$\mathrm{~T}_{4}$ - Oxadiazon@1.0 l/ha + HW at 45 DAT & 125000 & 131000 & 244300 & 299600 & 1.95 & 2.29 \\
$\mathrm{~T}_{5}$ - Oxadiazon@1.5 l/ha + HW at 45 DAT & 126000 & 134000 & 246400 & 311150 & 1.96 & 2.32 \\
$\mathrm{~T}_{6}$ - Oxadiazon@2.0 l/ha + HW at 45 DAT & 125000 & 136000 & 267050 & 334600 & 2.14 & 2.46 \\
$\mathrm{~T}_{7}$ - Pendimethalin@1.0 l/ha & 127000 & 128000 & 220150 & 264250 & 1.73 & 2.06 \\
$\mathrm{~T}_{8}$ - Pendimethalin@1.5 l/ha & 130000 & 130000 & 227850 & 268450 & 1.75 & 2.07 \\
$\mathrm{~T}_{9}$ - Pendimethalin@1.0 l/ha + HW at 45 DAT & 133000 & 133000 & 255150 & 287700 & 1.92 & 2.16 \\
$\mathrm{~T}_{10}$ - Pendimethalin@1.5 l/ha + HW at- 45 DAT & 135000 & 135000 & 242200 & 299950 & 1.79 & 2.22 \\
$\mathrm{~T}_{11}$ - Weed free & 160000 & 150000 & 212450 & 260400 & 1.33 & 1.74 \\
$\mathrm{~T}_{12}$-Weedy check (control) & 110000 & 125000 & 147700 & 219800 & 1.34 & 1.76 \\
\hline
\end{tabular}

Urea-Tk. 16/kg, TSP-Tk. 15kg-1, MoP-Tk.15 kg-1, Gypsum- Tk. $10 \mathrm{~kg}^{-1}$, Zinc sulphate -Tk.100 kg-1, Boric acid-Tk. $100 \mathrm{~kg}^{-1}$, Labour- Tk. 400 $\mathrm{man}^{-1}$ day $^{-1}$, Irrigation- 3000ha-1 irrigation ${ }^{-1}$, Leas value- Tk. $25000 \mathrm{ha}^{-1}$ for 5 months, Seed-1500 kg-1, Sale price-Tk. $30 \mathrm{~kg}^{-1}$ bulb in 2016 and Tk. $35 \mathrm{~kg}^{-1}$ bulb in 2017 .

\section{Conclusion}

Application of pre-emergence herbicide Oxadiazon@2.0 1/ha with one hand weeding at 45 days after transplanting showed highest weed control efficiency, benefit cost ratio and increased bulb yield of onion.

\section{References}

BBS.2019. Yearbook of Agricultural Statistics-2018.Bangladesh Bureau of Statistics. Statistics and Informatics Division (SID).Ministry of Planning. Government of the People's Republic of Bangladesh. Dhaka. 30:133.

Boyham, G.E., D.M. Granberry and W.T. Kelley. 2016. Green Onions: Commercial Vegetable Production.https://athenaeum.libs.uga.edu/bitstream/handle/10724/12353/C821.

Das, T.K. 2008. Weed science: Basics and applications. 1st Edition: Jain Brothers Publishers, New Delhi. 901p.

Devulkar, N.G., D.R. Bhanderi, S.J. More and B. Jethava. 2015. Optimization of yield and growth in onion through spacing and time of planting. Green Fmg. Int. J. 6: 305-307.

Dunan, C.M., P. Westra, F. Moore and P.Chapman.1996. Modelling the effect of duration of weed competition, weed density and weed competitiveness on seeded, irrigated onion. Weed Res. 36: 259-269.

Ghoshel, H.Z. 2004. Single herbicide treatments for control of broadleaved weeds in onion (Allium cepa L.) Crop Prot. 23: 539-542. 
Gomez, K.A. and A.A. Gomez.1984. Statistical procedures for agricultural research 2nd ed. John Wiley \& Sons, New York. pp.146-184.

James, R.L. and M.H.V. Harlen. 2010. Multiplication of reduced rate herbicides for weed control in onion. J. Weed Sci. Technol. 24: 153-159.

Karim, M.M., M.H. Khan, S. Ghosh, A.S.M.Y. Ali and M.A. Haque. 2014. Effect of different doses of oxadiazon herbicide on weed control in onion field. Eco-friendly Agric. J. 7(10): 115-118.

Kizilkaya, A., H. Onen and Z. Ozer. 2001. Researches on the effects of weed competition on onion yield. J. Turkish Weed Sci. 4(2): 58-65.

Misra, A.D., A. Kumar and W.I. Meitei. 2014. Effect of spacing and planting time on growth and yield of onion var. N-53 under Manipur Himalayas. Indian J. Hort.71(2): 207-210.

Naresh, K., I.B. Maurya and S.K. Intodia. 2002. Integrated weed management in onion (Allium cepa L.) seed crop in vertisols of south Rajasthan. Intl. J. Veg. Sci. 29(2): 191-192.

Nargis, B., M.S. Jilani and W. Kashif. 2006. Integrated weed management in different varieties of onion. Indus. J. Biol. Sci. 3(1): 678-684.

Panse, R., A. Gupta, P.K. Jain, D.S. Sasode and S. Sharma. 2014. Efficacy of different herbicides against weed flora in Onion (Allium cepa L.). J. Crop Weed.10(1): 163-166.

Patel, T.U., C.L. Patel, D.D. Patel, J.D. Thanki, M.K. Arvadia and H.B. Vaidya. 2012. Performance of onion under weed and fertilizer management. Indian J. Weed Sci. 44(3): 151-158.

Qasem, J.R. 2006. Chemical Weed Control in Seedbed Sown Onion (Allium cepa L.). Crop Prot. 25: 618-622.

Ray, N. and D.S. Yadav. 2005. Advance in vegetable production. Research book center. New Delhi. pp.237-238.

Smith, R., S.A. Fennimore, S. Orloff, G.J. Poole, C.E. Bell, D.W. Cudney, S.A. Fennimore and S. Orloff. 2008. Weeds (Flint ML editor). UC IPM Pest Management Guidelines: Onion and Garlic. University of California, Agriculture and Natural Resources, Publication. pp.34-53.

Syed, W.H. and M.F. Malik. 2001. Efficacy of cultural and chemical weed control in transplanted onion. J. Biol. Sci. 1(9): 825-827.

Uygur, S., R. Gurbuz and F.N. Uygur. 2010. Weeds of onion fields and effects of some herbicides on weeds in Cukurova region, Turkey. African J. Biotechnol. 9(42): 7037-7042.

Waiganjo, M.M. 2004. Studies on the distribution, ecology and preventive management of thrips (Thysanoptera: Thripidae) on onion in Kenya. PhD Thesis, Kenyatta University, Waiganjo, Nairobi. 211p. 